\title{
THE RELATIONSHIP BETWEEN FLOWERING PHENOLOGY AND POLLEN SEASONS OF ALNUS Miller
}

\author{
${ }^{1}$ Agnieszka Dąbrowska, ${ }^{2}$ Bogusław Michał Kaszewski
}

\author{
${ }^{1}$ Botanical Garden, University of Maria Curie-Skłodowska in Lublin, \\ Sławinkowska 3, 20-810 Lublin, Poland \\ ${ }^{2}$ Department of Meteorology and Climatology, University of Maria Curie-Skłodowska in Lublin, \\ Kraśnicka 2cd, 20-048 Lublin, Poland \\ e-mail: dabrowskaa@vp.pl
}

Received: 29.11.2011

\section{Abstract}

The dynamics of flowering and pollen release in anemophilous plants and the length of the particular phases depend largely on the geobotanical features of a region, its climate, meteorological factors, biological characteristics of vegetation, and abundance of pollen resources. The aim of the study was to determine the relationship between the flowering phases in eight Alnus taxa and the dynamics of occurrence and abundance of airborne pollen grains as well as the meteorological factors (maximum and minimum temperature, relative air humidity, maximum wind speed, and precipitation). The flowering phenophases and pollen seasons were studied in 2008-2011. Phenological observations of flowering were conducted in the Maria Curie-Skłodowska University Botanical Garden in Lublin and they involved the following taxa: Alnus crispa var. mollis, A. glutinosa, A. incana, A. incana 'Aurea', A. incana 'Pendula', A. maximowiczii, A. rubra and A. subcordata. Spearman's r correlation coefficients were calculated in order to determine the relationship between the dynamics of inflorescence development and meteorological conditions. Aerobiological monitoring using the gravimetric method was employed in the determination of Alnus pollen content in the air.

The annual phenological cycles in 2008-2011 varied distinctly in terms of the time of onset of successive flowering phases in the Alnus taxa studied, which depended largely on the taxonomic rank and meteorological factors. The following flowering sequence was revealed in the 2008-2011 growing seasons: A. subcordata (December or January), A. incana 'Pendula', A. incana, A. maximowiczii, A. rubra, A. glutinosa, A. incana 'Aurea' (February or March), and A. crispa var. mollis (April). The study demonstrated that the pollen of the taxa persisted in the air, on average, from mid-December to early May. The mean length of the flowering period, which coincided with various phases of the pollen season, was 17 days. The Alnus pollen season in 2008 started at the end of January and lasted until mid-March. In 2009, 2010, and 2011, the beginning of the pollen season was recorded in the first week of March and the end in the first week of April. The maximum concentration of airborne Alnus pollen was found at the full bloom stage of mainly A. glutinosa and A. rubra.

Inflorescence development was most closely related to temperature and relative air humidity; there was a weaker relationship with wind speed and precipitation.

Key words: Alnus spp., phenology, phenophase, flowering, meteorological factors, pollen season, aerobiology

\section{INTRODUCTION}

35 Alnus species are known to occur primarily in the cool temperate climatic zone of the northern hemisphere. The most common of them are A. glutinosa, A. incana and A. viridis (K r ü s s m a n n, 1976; R e h de r, 1977; Ball, 1980; Z a jąc and Zają c, 2001). Most species prefer humid habitats. In the wild, they are found in humid forests, along streams, in river valleys and on the shores of lakes, ponds, and other water bodies. They are monoecious, dioecious, anemophilous trees or shrubs. Male inflorescences are clustered in pendulous cylindrical inflorescences - catkins (Szafer et al. 1986; Seneta and Dolatowski, 2008). They are formed in the summer of the year preceding flowering ( $\mathrm{R} \mathrm{odkiew}$ i c z et al. 1996). A single flower is composed of 1-4 stamens and a quadripartite, small perianth. One male inflorescence contains an average of 580 flowers. One stamen produces an average of 8,420 pollen grains, whereas one inflorescence 19,534,000. Alder pollen grains are classified as small; they mostly have 5 , sometimes 4 or 6 pores with the characteristic 
thickened exine ( $a r c i)$ between the pores. The dimensions of the grains reach $24.2 \times 18.8 \mu \mathrm{m}$ (P i o trow $\mathrm{ska}, 2008$ ). Depending on the species, flowering precedes leaf development (late January, February or early March) or runs concurrently with the appearance of leaves in May (S z a f e r et al. 1986).

In the temperate climatic zone, most anemophilous tree species bloom during periods of unstable weather, which results in lack of regularity in the occurrence of successive phenophases in annual cycles (Hänninen, 1983; L a t tore, 1999; W e r y s zko-Chmielewska and Piotrowska, 2006; Puc, 2007; D ąbrowska, 2008; Pi otrow ska and $\mathrm{K}$ as zewski, 2009, 2011). Classic phenological observations provide important data about environmental changes (S o k o ł ow s ka, 1980; T o m a szewska and Rutkowski, 1999; Studer et al. 2007). The results of such investigations are widely used in a variety of scientific disciplines (ecology, biometeorology) and applied in agriculture, forestry and medical practice. Investigations of flowering phenology facilitate interpretation of aerobiological research results and ensure more precise allergy forecasts. This is especially important in forecasting the concentration of airborne pollen allergens (Orlandi et al. 2005; $\mathrm{Gal}$ a n, 2007). In recent aerobiological investigations, forecasting has been based mainly on the atmospheric factors (O rlandi et al. 2005). Currently, a biotic factor, i.e. flowering, is taken into account as well. The results obtained by J a to et al. (2002), K a sprzyk (2003), Estrella et al. (2006), Stach et al. (2006), Kasprzyk and Walanus (2007), Weryszko-Chmielewska and Sadowska (2010) indicate that these phenomena are, to a larger or lesser extent, interrelated and depend greatly on the geobotanical features and climate of a given region, the taxonomic rank of a particular plant, and the location of pollen sources.

The aims of the study include: (1) phenological observations of flowering of male inflorescences in eight Alnus taxa; (2) identification of relationships between the flowering phenophases in the eight Alnus taxa and some meteorological factors: maximum and minimum temperature, relative air humidity, maximum wind speed, and precipitation; (3) presentation of the pattern of the Alnus pollen seasons in Lublin in the years 2008-2011; (4) comparison of flowering phenophases with the dynamics and abundance of pollen grains in the atmospheric air.

\section{MATERIALS AND METHODS}

Flowering of male inflorescences and the pattern of Alnus pollen seasons were studied in 20082011. Flowering was observed in the Maria Curie-Skłodowska University Botanical Garden in Lublin and it involved eight taxa (Table 1 and Fig. 1). Among these, there were A. glutinosa naturally growing in the humid valley of the Garden and A. incana introduced as seedlings into the Garden from the Bieszczady Mountains. Plants from the other taxa were grown from seeds obtained from various other botanical gardens. The plants reached maturity (Table 1); they were fully acclimatized and in good condition, and produced flowers and viable seeds. Alnus crispa var. mollis is the only shrub taxon in the group studied; it reaches a height of $2.5 \mathrm{~m}$. The other taxa are 7-15 $\mathrm{m}$ high trees (Table 1).

Phenological observations of the flowering phases of the eight Alnus taxa (Table 1) were conducted following the method of $\mathrm{u} \mathrm{k} \mathrm{a} \mathrm{si} \mathrm{e} \mathrm{w} \mathrm{i} \mathrm{c} \mathrm{z} \mathrm{(1984).}$

There are six phenophases $(F)$ of the generative development of plants:

F2 - appearance of first flowers (several full-blown flowers),

F3 - onset of full bloom (about 25\% of open flowers),

F4 - appearance of first overblown flowers (first flowers with a wilting perianth),

F5 - end of full bloom (about 75\% of flowers overblown),

F6 - last blooming flower,

F7 - end of flowering (all flowers overblown).

The dates of the successive phenological phases were determined for each of the taxa.

Spearman's analysis was employed to compare the flowering phenophases in Alnus male inflorescences with meteorological parameters: maximum and minimum temperature, relative air humidity, maximum wind speed, and precipitation. Spearman's $\mathrm{r}$ correlation coefficients were calculated with the use of version 7.1 of the STATISTICA programme (StatSoft Inc., 2007). The data were obtained from the weather station of the UMCS Institute of Meteorology and Climatology situated $3 \mathrm{~km}$ from the sampling site.

The measurement of Alnus pollen fall was done by the gravimetric method with the use of a Durham sampler (D u r h a m, 1964). The sampler was placed in the western part of the city, in the Maria Curie-Skłodowska University Botanical Garden in Lublin $\left(51^{\circ} 16^{\prime} \mathrm{N}, 22^{\circ} 30^{\prime} \mathrm{E}\right), 5$ metres above ground $(220 \mathrm{~m}$ AMSL). Pollen fall was expressed as the number of pollen grains per $1 \mathrm{~cm}^{-2}$ of slide collected over two days.

\section{RESULTS}

\section{Flowering phenology}

The length of male inflorescences in the Alnus taxa measured before blooming ranged from 12 to $70 \mathrm{~mm}$ (Table 1 and Fig. 1A-H). The shortest inflorescences were found in the varieties A. crispa var. mollis and A. incana 'Aurea'; they were $14.5 \mathrm{~mm}$ on 
average (Fig. 1A, 1D). A. subcordata had the longest flowering, the inflorescence axis became elongated by inflorescences $-60 \mathrm{~mm}$ on average (Fig. 1H). During approximately 100\% (Table 1).
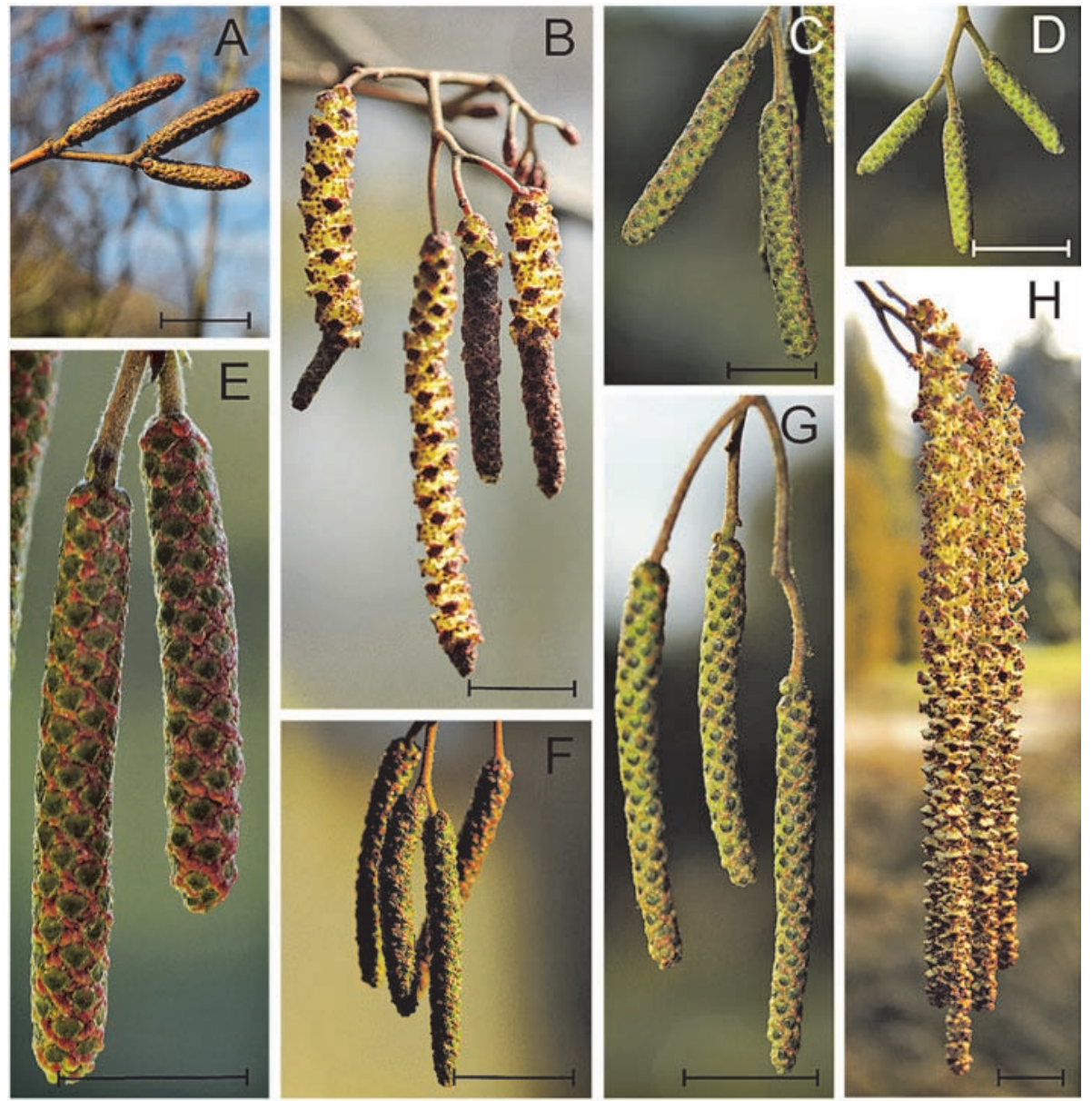

Fig. 1. Male inflorescences of eight Alnus taxa: A - Alnus crispa var. mollis, B - Alnus glutinosa, C - Alnus incana, D - Alnus incana 'Aurea', E-Alnus incana 'Pendula', F-Alnus maximowiczii, $\mathrm{G}$ - Alnus rubra, $\mathrm{H}$ - Alnus subcordata. A-H - scale bar $=10 \mathrm{~mm}$.

Table 1

Geographic distribution and short characteristics of eight Alnus taxa in the collection in the Maria Curie-Skłodowska University Botanical Garden in Lublin

\begin{tabular}{|c|c|c|c|c|}
\hline Taxon & Geographic distribution & $\begin{array}{l}\text { Age of taxa/ } \\
\text { number of } \\
\text { plants }\end{array}$ & $\begin{array}{l}\text { Height } \\
\text { (m) }\end{array}$ & $\begin{array}{l}\text { Length of } \\
\text { inflorescence } \\
\text { before and after } \\
\text { flowering }(\mathrm{mm})\end{array}$ \\
\hline Alnus crispa Pursh var. mollis (Fernald) Fernald & North America & $26 / 2$ & 2.5 & $12-17 / 71-76$ \\
\hline Alnus glutinosa (L.) Gaertn. & $\begin{array}{l}\text { Europe, Caucasus, Asia, } \\
\text { TR, Iran, North Africa, } \\
\text { North America }\end{array}$ & $15 / 3$ & 10 & $19-25 / 30-57$ \\
\hline Alnus incana (L.) Moench & $\begin{array}{l}\text { Europe, Caucasus, Siberia, } \\
\text { North America }\end{array}$ & $34 / 3$ & 12 & $23-36 / 69-78$ \\
\hline Alnus incana (L.) Moench 'Aurea' & cultivar & $24 / 2$ & 11 & $12-17 / 22-28$ \\
\hline Alnus incana (L.) Moench 'Pendula' & cultivar & $14 / 2$ & 7 & $26-37 / 69-76$ \\
\hline Alnus maximowiczii Callier & Japan, Sakhalin & $19 / 1$ & 8 & $22-24 / 37-44$ \\
\hline Alnus rubra Bong. & North America & $26 / 2$ & 9 & $22-33 / 37-57$ \\
\hline Alnus subcordata C.A. Мey. & Caucasus, Iran & $36 / 1$ & 15 & $50-70 / 110-120$ \\
\hline
\end{tabular}


Table 2

Flowering dates of male inflorescences of eight Alnus taxa, with the identification of phenological phases. F2 - appearance of first flowers (several full-blown flowers), F3 - onset of full bloom (about 25\% of open flowers), F4 - appearance of first overblown flowers (first flowers with a wilting perianth), F5 - end of full bloom (about 75\% of flowers overblown), F6 - last blooming flower, F7 - end of flowering (all flowers overblown)

\begin{tabular}{|c|c|c|c|c|c|}
\hline Taxon & Phenological phases & 2008 & 2009 & 2010 & 2011 \\
\hline \multirow{7}{*}{ Alnus crispa var. mollis } & $F 2$ & 25.04 & 23.04 & 23.04 & 22.04 \\
\hline & $F 3$ & 28.04 & 26.04 & 25.04 & 24.04 \\
\hline & F4 & 4.05 & 30.04 & 28.04 & 26.04 \\
\hline & F5 & 7.05 & 3.05 & 2.05 & 1.05 \\
\hline & F6 & 10.05 & 6.05 & 4.05 & 5.05 \\
\hline & $F 7$ & 11.05 & 7.05 & 5.05 & 6.05 \\
\hline & Duration of flowering (days) & 17 & 15 & 13 & 15 \\
\hline \multirow{7}{*}{ Alnus glutinosa } & $F 2$ & 23.02 & 26.03 & 19.03 & 24.03 \\
\hline & F3 & 25.02 & 28.03 & 21.03 & 28.03 \\
\hline & $F 4$ & 29.02 & 31.03 & 26.03 & 31.03 \\
\hline & F5 & 8.03 & 5.04 & 31.03 & 4.04 \\
\hline & F6 & 10.03 & 9.04 & 2.04 & 7.04 \\
\hline & $F 7$ & 11.03 & 10.04 & 3.04 & 8.04 \\
\hline & Duration of flowering (days) & 18 & 16 & 16 & 16 \\
\hline \multirow{7}{*}{ Alnus incana } & $F 2$ & 6.02 & 10.03 & 2.03 & 15.03 \\
\hline & $F 3$ & 9.02 & 15.03 & 18.03 & 18.03 \\
\hline & F4 & 12.02 & 28.03 & 21.03 & 22.03 \\
\hline & $F 5$ & 19.02 & 31.03 & 25.03 & 24.03 \\
\hline & F6 & 21.02 & 2.04 & 27.03 & 31.03 \\
\hline & $F 7$ & 22.02 & 3.04 & 28.03 & 1.04 \\
\hline & Duration of flowering (days) & 17 & 25 & 26 & 17 \\
\hline \multirow{7}{*}{ Alnus incana 'Aurea' } & $F 2$ & 25.02 & 31.03 & 20.03 & 15.03 \\
\hline & $F 3$ & 27.02 & 3.04 & 23.03 & 17.03 \\
\hline & F4 & 1.03 & 8.04 & 26.03 & 22.03 \\
\hline & F5 & 5.03 & 10.04 & 30.03 & 25.03 \\
\hline & F6 & 7.03 & 14.04 & 2.04 & 30.03 \\
\hline & $F 7$ & 8.03 & 15.04 & 3.04 & 31.03 \\
\hline & Duration of flowering (days) & 13 & 16 & 15 & 16 \\
\hline \multirow{7}{*}{ Alnus incana 'Pendula' } & $F 2$ & 1.02 & 3.03 & 17.03 & 15.03 \\
\hline & $F 3$ & 4.02 & 6.03 & 20.03 & 18.03 \\
\hline & $F 4$ & 7.02 & 11.03 & 23.03 & 24.03 \\
\hline & $F 5$ & 9.02 & 15.03 & 26.03 & 27.03 \\
\hline & F6 & 14.02 & 26.03 & 30.03 & 29.03 \\
\hline & $F 7$ & 15.02 & 27.03 & 31.03 & 30.03 \\
\hline & Duration of flowering (days) & 15 & 24 & 14 & 15 \\
\hline \multirow{7}{*}{ Alnus maximowiczii } & $F 2$ & 18.02 & 4.03 & 17.03 & 16.03 \\
\hline & $F 3$ & 22.02 & 10.03 & 19.03 & 18.03 \\
\hline & F4 & 25.02 & 15.03 & 21.03 & 21.03 \\
\hline & F5 & 27.02 & 21.03 & 26.03 & 25.03 \\
\hline & F6 & 29.02 & 23.03 & 30.03 & 29.03 \\
\hline & $F 7$ & 1.03 & 24.03 & 31.03 & 30.03 \\
\hline & Duration of flowering (days) & 13 & 20 & 14 & 14 \\
\hline \multirow{7}{*}{ Alnus rubra } & $F 2$ & 24.02 & 26.03 & 23.03 & 29.03 \\
\hline & F3 & 26.02 & 28.03 & 25.03 & 1.04 \\
\hline & F4 & 29.02 & 5.04 & 31.03 & 4.04 \\
\hline & $F 5$ & 5.03 & 9.04 & 4.04 & 7.04 \\
\hline & F6 & 7.03 & 14.04 & 9.04 & 10.04 \\
\hline & $F 7$ & 8.03 & 15.04 & 10.04 & 11.04 \\
\hline & Duration of flowering (days) & 14 & 21 & 19 & 14 \\
\hline \multirow{7}{*}{ Alnus subcordata } & $F 2$ & 10.01 & 7.12 & - & - \\
\hline & $F 3$ & 12.01 & 10.12 & - & - \\
\hline & F4 & 21.01 & 23.12 & - & - \\
\hline & F5 & 25.01 & 26.12 & - & - \\
\hline & F6 & 30.01 & 28.12 & - & - \\
\hline & $F 7$ & 31.01 & 29.12 & - & - \\
\hline & Duration of flowering (days) & 21 & 22 & - & - \\
\hline
\end{tabular}


The phenological observations demonstrated that, depending on the taxa and year of study, the onset of flowering (F2) took place between December 7 and April 25; the onset of full bloom (F3-F5) was between December 10 and May 7, and the end of flowering (F7) - between December 29 and May 11 (Table 2). The winter in 2008 was mild, therefore the growing period started earlier and most of the plants studied bloomed in February. In 2009, 2010 and 2011, flowering began in March. In the years 2008, 2009, 2010, and 2011, the mean temperature in February was 2.9, $-0.6,-1.6$, and $-3.6^{\circ} \mathrm{C}$, respectively, and in March 3.9, $2.1,3.8,3.3^{\circ} \mathrm{C}$. The mean length of flowering of the taxa studied was 17 days. Based on the phenological observations, a flowering calendar was established for the eight Alnus taxa, dividing them into very early: $A$. subcordata; early: A. incana 'Pendula', A. incana, and A. maximowiczii; medium early: A. rubra, A. glutinosa and A. incana 'Aurea'; and late taxa: A. crispa var. mollis. The first to bloom was A. subcordata, which grows naturally in the Caucasus and Iran. This species flowered abundantly in December or January and had the longest inflorescences (Tables 1, 2 and Fig. 1H); however, it was characterised by alternate flowering.
In 2009 and 2011, the plants did not flower (Table 2). In 2008, the onset of bloom of the early taxa $A$. incana 'Pendula', A. incana and A. maximowiczii took place in the first and second ten-day periods of February, whereas in 2009, 2010 and 2011 - in the first and second ten-day periods of March. The medium early taxa A. rubra, A. glutinosa and A. incana 'Aurea' flowered in the last week of February in 2008, and a month later in 2009, 2010 and 2011. A. crispa var. mollis, naturally occurring in North America, was the last to flower among the taxa studied. Each year, it bloomed at the end of April and continued until the beginning of May (Table 2). This species is related to $A$. viridis growing in Poland which also flowers at the turn of April and May.

\section{Spearman's r correlation coefficients}

The statistical analysis revealed statistically significant Spearman's $r$ correlation between the flowering rate of male inflorescences in the eight Alnus taxa and maximum and minimum temperature and relative air humidity during the four years of the study. The correlation between flowering dynamics and wind speed and precipitation was insignificant (Table 3 ).

Table 3

Pearson's r correlation coefficients for the growth male inflorescences of eight Alnus taxa and the weather parameters (2008-2011) $*$ - a statistically significant correlation coefficient $<0.01 ; * *<0.05$

\begin{tabular}{|c|c|c|c|c|c|c|}
\hline Taxon & Year & $\begin{array}{l}\text { Max. temp. } \\
\left(\mathrm{C}^{\circ}\right)\end{array}$ & $\begin{array}{l}\text { Min. temp. } \\
\left(\mathrm{C}^{\circ}\right)\end{array}$ & $\begin{array}{c}\text { Relative } \\
\text { humidity (\%) }\end{array}$ & $\begin{array}{l}\text { Max. wind } \\
(\mathrm{m} / \mathrm{s})\end{array}$ & $\begin{array}{c}\text { Precipitation } \\
(\mathrm{mm})\end{array}$ \\
\hline Alnus crispa var. mollis & $\begin{array}{l}2008 \\
2009 \\
2010 \\
1011 \\
\end{array}$ & $\begin{array}{l}\mathbf{0 . 8 4} * \\
0.29 \\
0.66 \\
\mathbf{0 . 8 3} * \\
\end{array}$ & $\begin{array}{l}\mathbf{- 0 . 7 6 *} \\
-0.22 \\
0.35 \\
\mathbf{0 . 6 4 * *} \\
\end{array}$ & $\begin{array}{l}-0.29 \\
-0.38 \\
-0.50 \\
-\mathbf{0 . 6 8} * * \\
\end{array}$ & $\begin{array}{r}-0.03 \\
-0.40 \\
0.50 \\
-0.52 \\
\end{array}$ & $\begin{array}{l}-0.05 \\
-0.20 \\
-0.65 \\
-0.53 \\
\end{array}$ \\
\hline Alnus glutinosa & $\begin{array}{l}2008 \\
2009 \\
2010 \\
1011 \\
\end{array}$ & $\begin{array}{l}0.44 * * \\
0.89 * \\
0.79 * \\
0.66^{* *} \\
\end{array}$ & $\begin{array}{c}0.32 \\
\mathbf{- 0 . 7 5 *} \\
\mathbf{0 . 6 9} * \\
0.52 \\
\end{array}$ & $\begin{array}{l}-0.50 \\
\mathbf{- 0 . 7 7} * \\
\mathbf{- 0 . 6 2} * * \\
-0.50 \\
\end{array}$ & $\begin{array}{l}-0.13 \\
\mathbf{- 0 . 4 7} * * \\
0.16 \\
0.26\end{array}$ & $\begin{array}{r}0.02 \\
-0.39 \\
0.24 \\
-0.43 \\
\end{array}$ \\
\hline Alnus incana & $\begin{array}{l}2008 \\
2009 \\
2010 \\
1011 \\
\end{array}$ & $\begin{array}{l}0.37 \\
0.42 \\
0.84 * \\
0.74 * \\
\end{array}$ & $\begin{array}{l}0.42 \\
0.44 \\
\mathbf{0 . 7 2} * \\
\mathbf{0 . 5 9} * * \\
\end{array}$ & $\begin{array}{l}\mathbf{- 0 . 4 6} * * \\
-0.47 \\
\mathbf{- 0 . 6 9} * * \\
-0.38 \\
\end{array}$ & $\begin{array}{r}-0.01 \\
-0.28 \\
0.48 \\
0.08 \\
\end{array}$ & $\begin{array}{r}0.06 \\
0.13 \\
-0.16 \\
-0.55 \\
\end{array}$ \\
\hline Alnus incana 'Aurea' & $\begin{array}{l}2008 \\
2009 \\
2010 \\
1011 \\
\end{array}$ & $\begin{array}{l}0.21 \\
0.85 * \\
0.63 * * \\
0.65 * * \\
\end{array}$ & $\begin{array}{l}0.23 \\
\mathbf{0 . 7 1} * \\
0.54 \\
0.55 \\
\end{array}$ & $\begin{array}{l}-0.37 \\
-0.61 \\
-0.54 \\
-0.45 \\
\end{array}$ & $\begin{array}{r}0.16 \\
-0.43 \\
0.43 \\
0.19 \\
\end{array}$ & $\begin{array}{l}-0.10 \\
\mathbf{- 0 . 5 3} * * \\
0.21 \\
-0.37 \\
\end{array}$ \\
\hline Alnus incana 'Pendula' & $\begin{array}{l}2008 \\
2009 \\
2010 \\
1011 \\
\end{array}$ & $\begin{array}{l}0.06 \\
0.38 \\
0.79 * \\
0.64 * * \\
\end{array}$ & $\begin{array}{l}0.14 \\
0.15 \\
\mathbf{0 . 6 9} * * \\
0.41 \\
\end{array}$ & $\begin{array}{l}-0.15 \\
-0.66 \\
\mathbf{- 0 . 7 2} * \\
-0.28 \\
\end{array}$ & $\begin{array}{l}-0.19 \\
-0.02 \\
\mathbf{0 . 7 4} * \\
0.38 \\
\end{array}$ & $\begin{array}{r}0.23 \\
0.21 \\
-0.11 \\
-0.43 \\
\end{array}$ \\
\hline Alnus maximowiczii & $\begin{array}{l}2008 \\
2009 \\
2010 \\
1011 \\
\end{array}$ & $\begin{array}{l}0.47 * * \\
0.80 * \\
0.67 * \\
0.67 * * \\
\end{array}$ & $\begin{array}{l}-0.46 \\
-\mathbf{0 . 7 7} * \\
\mathbf{0 . 6 4} * \\
0.39 \\
\end{array}$ & $\begin{array}{l}\mathbf{- 0 . 4 9} * * \\
-0.35 \\
-0.37 \\
\mathbf{- 0 . 6 7} * * \\
\end{array}$ & $\begin{array}{l}0.14 \\
0.09 \\
0.11 \\
0.11 \\
\end{array}$ & $\begin{array}{c}0.08 \\
-0.30 \\
0.06 \\
\mathbf{- 0 . 6 2} * * \\
\end{array}$ \\
\hline Alnus rubra & $\begin{array}{l}2008 \\
2009 \\
2010 \\
1011 \\
\end{array}$ & $\begin{array}{l}\mathbf{0 . 5 9} * \\
\mathbf{0 . 7 4} * \\
\mathbf{0 . 6 5} * \\
0.53 \\
\end{array}$ & $\begin{array}{l}\mathbf{- 0 . 5 2} * * \\
0.51 \\
\mathbf{0 . 5 8} * * \\
0.47 \\
\end{array}$ & $\begin{array}{l}\mathbf{- 0 . 5 4} * * \\
\mathbf{- 0 . 6 6} * * \\
-0.24 \\
-0.38 \\
\end{array}$ & $\begin{array}{r}0.05 \\
-0.28 \\
0.13 \\
0.06 \\
\end{array}$ & $\begin{array}{c}-0.01 \\
-0.22 \\
0.32 \\
-0.32 \\
\end{array}$ \\
\hline Alnus subcordata & $\begin{array}{l}2008 \\
2009 \\
2010 \\
2011\end{array}$ & $\begin{array}{l}0.02 \\
0.56 * \\
- \\
-\end{array}$ & $\begin{array}{c}-0.27 \\
\mathbf{- 0 . 6 5} * \\
- \\
-\end{array}$ & $\begin{array}{c}-0.07 \\
-0.32 \\
- \\
-\end{array}$ & $\begin{array}{c}-0.10 \\
0.41 \\
- \\
-\end{array}$ & $\begin{array}{c}0.02 \\
0.59 \\
- \\
-\end{array}$ \\
\hline
\end{tabular}




\section{Characteristics of the pollen seasons}

The pattern of the Alnus pollen seasons in Lublin in the years 2008-2011 varied substantially (Table 4). In 2008 Alnus pollen grains appeared in the aeroplankton as early as on January 30 and persisted until March 18. The maximum pollen concentration was observed between February 26 and 27. In the subsequent study years (2009-2011), the pollen seasons started much later, as late as the first week of March, and ended in the first week of April. The maximum pollen concentration was observed on March 30 and 31 in 2009 and 2011, and on March 25 and 26 in 2010. The pollen seasons in the last three study years (2009-2011) were characterised by regularity in the appearance of the successive phases in the annual cycles. The time span between the dates of the onset of pollen seasons in the years 2009-2011 was only 5 days (March 1-5), whereas in the whole study period it reached 34 days (January 30 to March 5) (Table 4).

Table 4

Characteristics of the Alnus pollen seasons on the basis of aerobiological monitoring in Lublin, in the period 2008-2011

\begin{tabular}{lllll}
\hline Investigated trait & 2008 & 2009 & 2010 & 2011 \\
\hline Start of season & 30.01 & 3.03 & 1.03 & 5.03 \\
End of season & 18.03 & 4.04 & 6.04 & 7.04 \\
Duration (days) & 48 & 32 & 37 & 33 \\
Max. concentration (number of grains $/ \mathrm{cm}^{2}$ ) & 246 & 165 & 226 & 184 \\
Date of occurrence of max. concentration & $26-27.02$ & $30-31.03$ & $25-26.03$ & $30-31.03$ \\
\hline Total pollen & 1456 & 324 & 1025 & 857 \\
\hline
\end{tabular}

\section{Comparison of flowering phenology and pollen release in Alnus}

The length of the pollen season ranged from 4.5 to 7 weeks, depending on the year (Table 4). In that period, the majority of the Alnus taxa studied flowered, except for A. subcordata, which bloomed before the recorded pollen season, and A. crispa var. mollis, which flowered after the season (Table 2 and Figs 2-5). Flowering of the taxa usually lasted over two weeks and coincided with various phases of the pollen season. With the exception of $A$. subcordata and A. crispa var. mollis, the total length was 6 weeks, which largely corresponded to the length of the pollen season (Figs 2-5). The picture of the pollen season was under the impact of A. glutinosa and A. incana pollen grains, since they occurred abundantly near the sampling site.
A. glutinosa and A. rubra flowered in the middle of the pollen season and full bloom coincided with the time of maximum concentrations of airborne Alnus pollen. In the case of the other taxa, full bloom did not usually accompany the maximum concentration of pollen grains in the air (Tables 2 and 4), which was related to the biological features of the taxon. The exception was only the year 2010 .

In 2009 and 2011, four of the taxa studied: A. subcordata, A. glutinosa, A. incana and A. rubra, produced considerably fewer or no male inflorescences. These data are consistent with the lower annual sum of airborne pollen grains (Table 4). Alternate flowering was observed in fully mature trees. Moreover, some of A. glutinosa and A. rubra inflorescences wilted at the top or along the entire length.

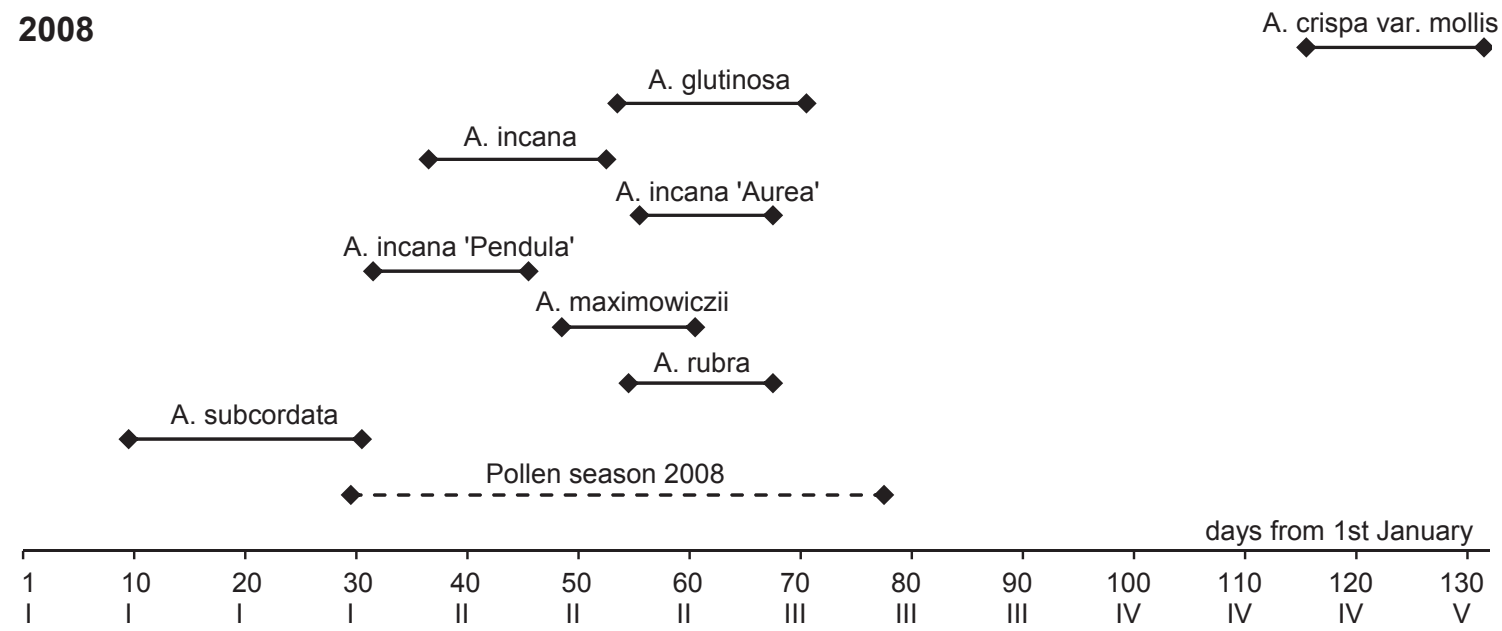

Fig. 2. The start and end dates of flowering and the pollen season of Alnus in 2008. 
2009

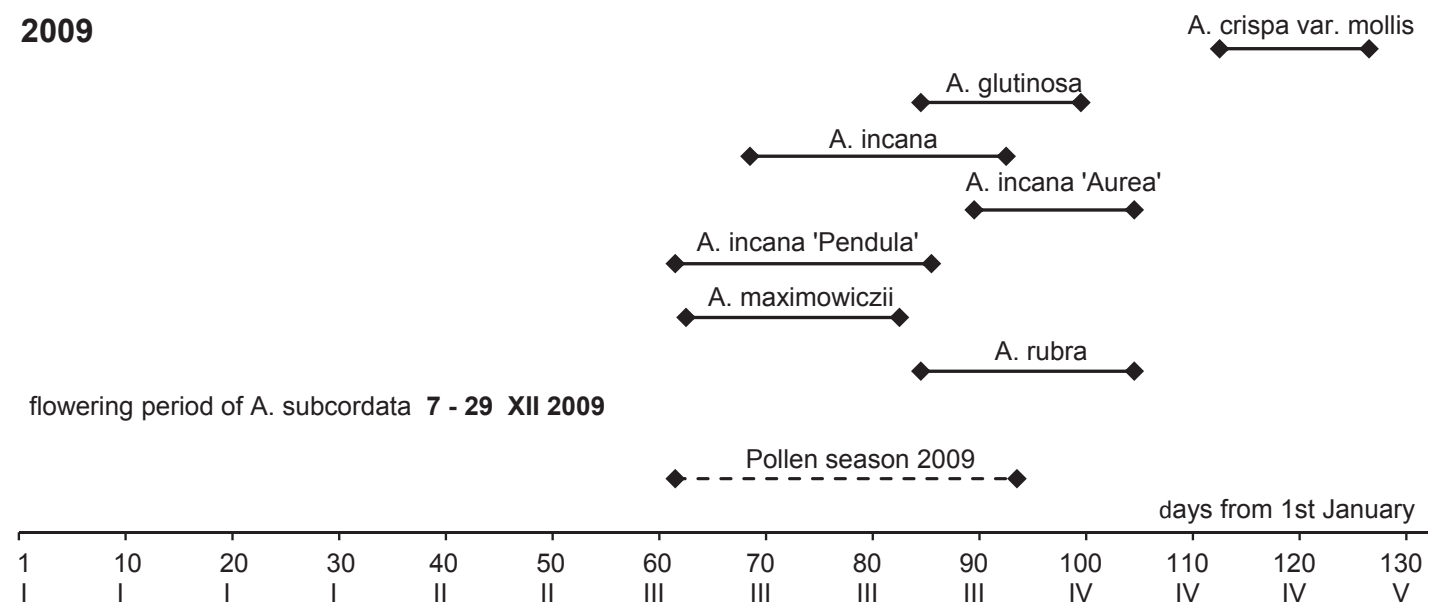

A. crispa var. mollis

Fig. 3. The start and end dates of flowering and the pollen season of Alnus in 2009.

2010

A. crispa var. mollis

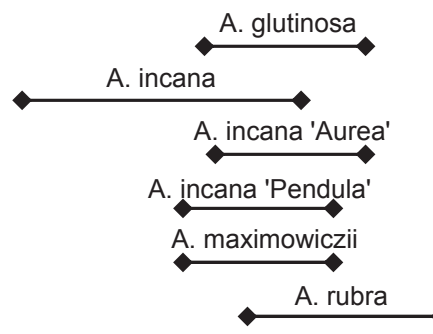

A. subcordata not flowering 2010

Pollen season 2010

\begin{tabular}{|c|c|c|c|c|c|c|c|c|c|c|c|c|c|}
\hline & & & & & & & $\begin{array}{l}\text { Poll } \\
--\end{array}$ & easol & - & & days $f$ & $1 \mathrm{st}$ & \\
\hline & 10 & 20 & 30 & 40 & 50 & 60 & 70 & 80 & 90 & 100 & 110 & 120 & 130 \\
\hline I & 1 & I & 1 & $\|$ & II & III & III & III & III & IV & IV & IV & V \\
\hline
\end{tabular}

Fig. 4. The start and end dates of flowering and the pollen season of Alnus in 2010.

2011
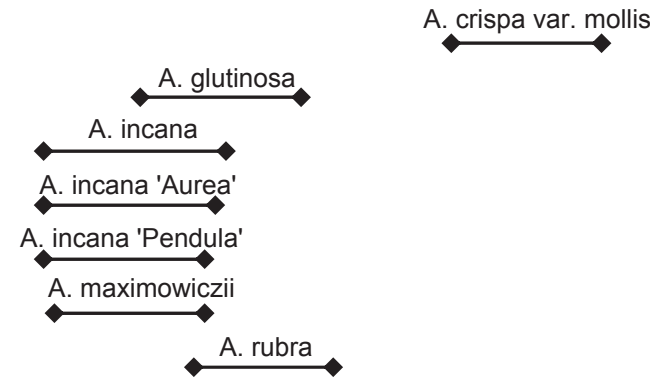

A. subcordata not flowering 2011

Pollen season 2011

days from 1 st January

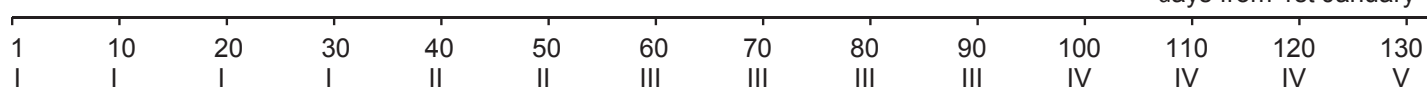

Fig. 5. The start and end dates of flowering and the pollen season of Alnus in 2011.

\section{DISCUSSION}

In phenology, the onset of flowering in A. glutinosa and A. incana is referred to as one of the most important traits for determination of the beginning of vegetation (beginning of early spring). In our country, early spring begins on March 15 and lasts until April 10. The earliest beginning (around March 15) is noted in the north-west and south of Poland. After March 20, early spring begins in the west, in a belt extending from the western seacoast down to the Sudety Mountains 
and Krakowsko-Częstochowska Upland in the south. After April 5, early spring starts in the north-eastern part of Poland comprising the eastern coast, the regions of Warmia and Mazury, Suwalszczyzna, and a part of the Białostocka Plateau (T o m a s z e w s ka and R u tk ow s ki, 1999).

In the recent decade, the dates of the beginning and end of the Alnus pollen season varied between different pollen monitoring sites in Poland: in Szczecin it was February 20 and April 2 (P u c , 2007), in Poznań - February 10 and April 12 (S t a c h , 2006), in Sosnowiec - February 19 and April 11 (Chłope k and D ą b row s k a , 2006), in Kraków - February 25 and April 3 (Mys zkow ska, 2006; M y s zkow $\mathrm{s} k$ a et al. 2007), in Warsaw - February 26 and April 2 (Weryszko-Chmielewska and Rapiejko, 2007), in Lublin - February 28 and April 16 (W e ryszko-Chmielewska and Piotrowska, 2006; Weryszko-Chmielewska and Rapiejko, 2007; Dąbrowska, 2008), and in Rzeszów - March 4 and April 12 (K a s pr z y k, 2006). According to our phenological observations and those of Tomaszewska and Rutkowski (1999), the onset of Alnus flowering did not coincide with presence of pollen grains in the aeroplankton in the above-mentioned Polish cities. The pollen seasons were observed much earlier than the onset of flowering. The spatial distribution of the occurrence of Alnus pollen grains in the aeroplankton in Poland displayed similarity with the map of spring warming progressing from the south-west and west towards the north-east.

The relationship between the occurrence of airborne pollen and the flowering pattern is obvious, although not always close. This has been confirmed in literature (L a t to re, 1999; J a to et al. 2002; K a sprzyk, 2003; Estrella et al. 2006; Stach et al. 2006; Kasprzyk and Walanus, 2007; Weryszko-Chmielewska and Sadowska, 2010) and presented in the results. Generally, the pollen season is longer than the flowering period, as all pollen grains from both secondary pollen deposition and long-distance transport are taken into account. The differences between the two phenomena arise from genetic and physiological features of plants (H ä n n i n e n, 1983), geobotanic conditions and the climate in a given region as well as research methodology ( $\mathrm{J}$ a to et al. 2002; E s tre 11 a et al. 2006; S t a c h et al. 2006). Most anemophilous trees bloom during periods of unstable weather, which leads to irregularities in the onsets of the successive phenophases in the annual cycles ( $\mathrm{H}$ än ninen, 1983; Puc, 2007; D ą browska, 2008; Piotrowska and Kaszewski, 2009, 2011). Tree pollen grains are released at high altitudes, get to the higher layers of the atmosphere and, theoretically, they may be transported over long distances. The transport of pollen grains in the atmosphere depends on their shape and the rate of fall-out. Pollen grains of many tree species are aerodynamically shaped and they remain in the air for a long time, increasing the chance of long distance transport (S z c z e p a n e k, 2003). The gravimetric method more distinctly reveals the effect of local factors on the content of pollen spectra, and particularly on the occurrence of pollen from secondary sources, which is primarily manifested by the presence of out-of-season pollen in the annual cycles.

The genus Alnus is characterized by alternate flowering and fruiting. This is reflected in the periodic fluctuation of fertility (D ą b row s ka, 2008; Kas zewski et al. 2008; Pidek et al. 2008). Some Alnus species and varieties have exhibited a tendency toward fluctuations in a biennial cycle - strong fruiting during one year was followed by weaker, and then stronger fruiting again. Alternate flowering and fruiting usually occurred in fully mature plants and intensified along with aging. This phenomenon can be observed in trees with a tendency toward production of excessive numbers of fruit ( $\mathrm{J} \mathrm{a} \mathrm{n} \mathrm{ki} \mathrm{e} \mathrm{w} \mathrm{i} \mathrm{c} \mathrm{z} \mathrm{and} \mathrm{Li}$ pecki, 2011).

\section{CONCLUSIONS}

1. The annual phenological cycles in the early-flowering Alnus taxa differed clearly in terms of the onset of the consecutive phases. The difference between the flowering start dates in 2008-2011 was, on average, 31 days. This phenomenon was undoubtedly related to the different weather conditions prevailing throughout the study years. Flowering of A. crispa var. mollis in the late-spring months did not exhibit such deviations, as the difference between the dates of flowering onset during the 4 years was only 4 days.

2. Statistically significant Spearman's correlations were found between the dynamics of evolution of Alnus male inflorescences and maximum and minimum air temperatures as well as relative air humidity.

3. The analysis of comparative pictures of the occurrence of Alnus pollen grains in the aeroplankton in Lublin showed that their appearance, prevalence, and tendencies in abundance differed significantly between the particular study years.

4. The taxa studied flowered on average 17 days and this coincided with different phases of the pollen season. The maximum concentration of Alnus pollen grains in the air coincided with the full bloom period, mainly of A. glutinosa and A. rubra.

\section{Acknowledgements}

I wish to thank G. Szymczak, PhD, R. Sawicki, $\mathrm{MSc}$, and $\mathrm{M}$. Czernecki, $\mathrm{PhD}$, for providing the research material. 


\section{REFERENCES}

Ball P.W., 1980. Alnus Miller. [In:] T.G. Tutin, V.H. Heywood, N.A. Burges, D.M. Moore, D.H. Valentine, S.M. Walters, D.A. Webb (eds), Flora Europaea 1, Cambridge University Press, Cambridge: 59.

Chłopek K., Dąbrowska K., 2006. Pyłek wybranych taksonów roślin w powietrzu Sosnowca, 2001-2005. [In:] E. Weryszko-Chmielewska (ed.), Pyłek roślin w aeroplanktonie różnych regionów Polski. Katedra i Zakład Farmakognozji AM w Lublinie: 59-69. (in Polish)

Dąbrowska A., 2008. The influence of weather conditions on the course of pollen seasons of alder (Alnus spp.), hazel (Corylus spp.) and birch (Betula spp.) in Lublin (2001-2006). Acta Agrobot. 61(1): 53-57.

Durham O.C., 1964. Proposed standard method of gravity sampling. J. Allergy, 17: 79.

Estrella N., Menzel A., Krämer U., Behrendt H., 2006. Integration of flowering dates in phenology and pollen counts in aerobiology: analysis of their spatial and temporal coherence in Germany (1992-1999). Int. J. Biometeorol. 51: 49-59.

Gala n C., 2007. Recent phenology methods applied to aerobiology. [In:] AEROTOP Workshop. Phenology, forecasting and airborne allergens. 18-20 $0^{\text {th }}$ May, Poznań: 1-13.

Hänn inen H., 1983. A method for identifying the flowering season from aerobiological data. [In:] Nordic Aerobiology. 5th Nord. Symp. Aerobiol. Sweden.: 51-57.

Jankiewicz L.S., Lipecki J., 2011. Fizjologia roślin sadowniczych strefy umiarkowanej. Wydawnictwo Naukowe PWN, Warszawa. (in Polish)

Jato V., Méndez J., Rodríuez-Rajo J., Seijo C., 2002. The relationship between the flowering phenophase and airborne pollen of Betula in Galicia (N.W. Spain). Aerobiol. 18: 55-61.

Kasprzyk I., 2003. Flowering phenology and airborne pollen grains of chosen tree taxa in Rzeszów, SE Poland. Aerobiologia, 19: 113-120.

Kasprzyk I., 2006. Pyłek wybranych taksonów roślin w powietrzu Rzeszowa w latach 2001-2005. [In:] E. Weryszko-Chmielewska (ed.). Pyłek roślin w aeroplanktonie różnych regionów Polski. Katedra i Zakład Farmakognozji AM w Lublinie: 93-103. (in Polish)

Kasprzyk I., Wal anus A., 2007. Flowering and airborne pollen - a new tool of comparison data. Acta Agrobot. 60(2): 51-55.

Kaszewski B.M., Pidek I.A., Piotrowska K., Weryszko-Chmielewska E., 2008. Annual pollen sums of Alnus in Lublin and Roztocze in the years 2001-2007 against selected meteorological parameters. Acta Agrobot. 61(2): 57-64.

K r ü s s m a n n G., 1976. Handbuch der Laubgehölze 1. Verlag Paul Parey, Berlin und Hamburg: 138-147. (in German)

Lattore F., 1999. Differences between airborne pollen and flowering phenology of urban trees with reference to production, dispersal and interannual climate variability. Aerobiol. 15: 131-141.
Łukasiewicz A., 1984. Potrzeba ujednolicenia metodyki fenologicznej w polskich ogrodach botanicznych i arboretach. / The need to standardise the phenological metod in Polish botanical garden and arboreta. Wiad. Bot. 28(2): 153-158. (in Polish)

Myszkowska D., 2006. Pyłek wybranych taksonów roślin w powietrzu Krakowa, 2001-2005. [In:] E. Weryszko-Chmielewska (ed.), Pyłek roślin w aeroplanktonie różnych regionów Polski. Katedra i Zakład Farmakognozji AM w Lublinie: 21-30. (in Polish)

Myszkowska D., Jenner B., Cywa K., Kuropatwa M., Stępalska D., Piotrowicz K., 2007. Pollen seasons of selected tree and shrub taxa in Kraków and its neighbourhood. Acta Agrobot. 62(2): 71-77.

Orlandi F., Vazguez L.M., Ruga L., Bonofiglio T., Fornaciari M., Garcia-Mozo H., Dominguez E., Romano B., Galan C., 2005. Bioclimatic requirements for olive flowering in two Mediterranean regions located at the same latitude (Andalusia, Spain, and Sicily, Italy). Ann. Agric. Environ. Med. 12: 47-52.

Pidek I.A., Weryszko-Chmielewska E., Piot row ska K., 2008. Czy istnieje dwuletni rytm obfitego pylenia brzozy i olszy? / Does the biannual rhythm of abundant birch and alder flowering exist? Alergologia. Immunologia, 5(2): 61-65. (in Polish)

Piotrowska K., 2008. Ecological features of flowers and the amount of pollen released in Corylus avellana (L.) and Alnus glutinosa (L.) Gaertn. Acta Agrobot. 61(1): 33-39.

Piotrowska K., Kaszewski B.M., 2009. The influence of meteorological conditions on the start of the hazel (Corylus L.) pollen season in Lublin, 2001-2009. Acta Agrobot. 62(2): 59-66.

Piotrowska K., Kaszewski B.M., 2011. Variations in birch pollen (Betula spp.) seasons in Lublin and correlations with meteorological factors in the period 20012010. A preliminary study. Acta Agrobot. 64(2): 39-50.

$\mathrm{Puc}$ M., 2007. The effect of meteorological conditions on hazel (Corylus spp.) and alder (Alnus spp.) pollen concentration in the air of Szczecin. Acta Agrobot. 60(2): 65-70.

Rehder A., 1977. Manual of cultivated trees and shrubs. Hardy in North America. Exclusive of the subtropical and warmer temperate regions. Macmillan Publishing, New York : 135-139.

Rodkiewicz B., Śnieżko R., Fyk B., Niewęgłowska B., Tchórzewska D., 1996. Embriologia Angiospermae rozwojowa i eksperymentalna. / Developmental and experimental embryology of Angiospermae. Wydawnictwo UMCS, Lublin. (in Polish).

Seneta W., Dolatowski J., 2008. Dendrologia. Wydawnictwo Naukowe PWN, Warszawa: 131-133. (in Polish)

Sokołowska J., 1980. Przewodnik fenologiczny. Inst. Meteorologii i Gospodarki Wodnej. Wyd. Łączności i Kom., Warszawa. (in Polish) 
S t a ch A., 2006. Pyłek wybranych taksonów roślin w powietrzu Poznania, 2001-2005. [In:] E. Weryszko-Chmielewska (ed.), Pyłek roślin w aeroplanktonie różnych regionów Polski. Katedra i Zakład Farmakognozji AM w Lublinie: 31-47. (in Polish)

Stach A., Kluza-Wieloch M., Zientarska A., 2006. The phenology of flowering and fluctuations of airborne pollen concentrations of selected trees in Poznań, 2003-2004. Acta Agrobot. 59(1): 301-308.

$\mathrm{St}$ a $\mathrm{S}$ of $\mathrm{t}$ IN C., 2007. STATISTICA (data analysis software system), version 7.0. www.statsoft.com.

Studer S., Stöckli R., Appenzeller C., Vidale P.L., 2007. A comparative study of satellite and ground-based phenology. Int. J. Biometeorol. 5: 405414.

Szafer W., Kulczyński S., Pawłowski B., 1986. Rośliny polskie. Opisy i klucze do oznaczania wszystkich gatunków roślin naczyniowych rosnących w Polsce bądź dziko, bądź też zdziczałych lub częściej hodowlanych. Państwowe Wydawnictwo Naukowe, Warszawa. (in Polish)

Szczepanek K., 2003. Wytwarzanie i rozprzestrzenianie spor i ziarn pyłku. / Production and dispersal of spores and pollen grains. [In:] S. Dybova-Jachowicz, A. Sadowska (eds), Palinologia. Wyd. Inst. Botaniki PAN, Kraków: 16-28. (in Polish)

Tomaszewska T., Rutkowski Z., 1999. Fenologiczne pory roku i ich zmienność w wieloleciu 1951-1990. / Phenological seasons and its variability in the years 1951-1990. Materiały Badawcze, seria: Meteorologia 28, Inst. Meteorologii i Gospodarki Wodnej, Warszawa. (in Polish)

Weryszko-Chmielewska E., Piotrowska K., 2006. Pyłek wybranych taksonów roślin w powietrzu Lublina w latach 2001-2005. [In:] E. Weryszko-Chmielewska (ed.), Pyłek roślin w aeroplanktonie różnych regionów Polski. Katedra i Zakład Farmakognozji AM w Lublinie: 105-115. (in Polish)

Weryszko-Chmielewska E., Rapiejko P., 2007. Analysis of Alnus spp. pollen seasons in Lublin and Warsaw (Poland), 2001-2007. Acta Agrobot. 60(2): 87-97.

Weryszko-Chmielewska E., Sadowska D.A., 2010. The phenology of flowering and pollen release in four species of linden (Tilia L.). J. Apicultural Sci. 54(2): 99-108.

Zając A., Zając M. (eds.), 2001. Distribution atlas of vascular plants in Poland. Pracownia Chorologii Komputerowej Inst. Bot. UJ, Kraków.

\section{Zależność pomiędzy fenologią kwitnienia i sezonami pyłkowymi Alnus Miller}

\section{Streszczenie}

Dynamika kwitnienia i pylenia roślin wiatropylnych oraz czas trwania ich poszczególnych faz zależy od właściwości geobotanicznych regionu, klimatu, warunków pogodowych, właściwości biologicznych roślin oraz obfitości źródeł pyłku. Celem badań było ustalenie zależności między fazami kwitnienia ośmiu taksonów Alnus a dynamiką i obfitością występowania ziaren pyłku w powietrzu atmosferycznym oraz warunkami pogodowymi (temperatura maksymalną i minimalną, wilgotnością względną powietrza, maksymalną prędkością wiatru i opadami). Fenofazy związane z kwitnieniem oraz przebieg sezonów pyłkowych badano w latach 2008-2011. Obserwacje fenologiczne kwitnienia wykonano na wybranych taksonach: Alnus crispa var. mollis, A. glutinosa, A. incana, A. incana 'Aurea', A. incana 'Pendula', A. maximowiczii, A. rubra i A. subcordata w Ogrodzie Botanicznym Uniwersytetu Marii CurieSkłodowskiej. Współczynniki korelacji r Spearmana wyliczono w celu zbadania zależności pomiędzy dynamiką rozwoju kwiatostanu a warunkami pogodowymi. Do badań zawartości pyłku Alnus w powietrzu zastosowano monitoring aerobiologiczny przeprowadzony metodą grawimetryczną.

Roczne cykle fenologiczne w latach 2008-2011 różniły się wyraźnie czasem rozpoczęcia kolejnych faz kwitnienia badanych taksonów Alnus, co było w znacznej mierze zależne od rangi taksonomicznej, a także warunków pogodowych. Wykazano, że w sezonach wegetacyjnych 2008-2011 zakwitły kolejno A. subcordata (w grudniu lub w styczniu), A. incana 'Pendula', A. incana, A. maximowiczii, A. rubra, A. glutinosa, $A$. incana 'Aurea' (w lutym lub w marcu) i A. crispa var. mollis (w kwietniu). Z badań wynika, że pyłek badanych taksonów występował w powietrzu średnio od połowy grudnia do początku maja. Średnia długość kwitnienia wymienionych taksonów wynosiła 17 dni i przypadała w różnych fazach sezonu pyłkowego. Sezon pyłkowy Alnus w roku 2008 rozpoczynał się pod koniec stycznia i trwał do połowy marca. W latach 2009, 2010 i 2011 początek pylenia notowano $\mathrm{w}$ pierwszym tygodniu marca a koniec w pierwszym tygodniu kwietnia. Maksymalne stężenie pyłku Alnus w powietrzu przypadało na okres pełni kwitnienia głównie A. glutinosa i A. rubra.

Rozwój kwiatostanów wykazywał najsilniejszy związek z temperaturą i wilgotnością względną powietrza, słabszy z prędkością wiatru i opadem atmosferycznym. 